\title{
PERAN KOHERENSI DIRI TERHADAP RESILIENSI KELUARGA PADA ORANG TUA TUNGGAL
}

\author{
Cut Helena dan Melok Roro Kinanthi \\ Fakultas Psikologi, Universitas YARSI \\ J1. Letjen Soeprapto, Cempaka Putih, Jakarta Pusat 10510 \\ E-mail: melok.roro@yarsi.ac.id
}

\begin{abstract}
ABSTRAK
Keluarga dengan orang tua tunggal rentan mengalami tekanan atau situasi sulit. Agar dapat beradaptasi secara optimal, perlu dipastikan keluarga resilien. Dengan demikian, penting untuk mengetahui faktor yang berkontribusi terhadap resiliensi keluarga. Penelitian ini bertujuan untuk mengetahui peran koherensi diri terhadap resiliensi keluarga dengan orang tua tunggal, yakni ibu. Penelitian ini dilakukan dengan pendekatan kuantitatif dan desain asosiatif. Partisipan yang terlibat dalam penelitian sebanyak 104 orang, yakni ibu yang merupakan orang tua tunggal, yang dipilih melalui convenience sampling. Instrumen pengumpulan data yang digunakan adalah Sense of Coherence 13 (Antonovsky \& Sourani, 1988) untuk mengukur koherensi diri dan Walsh Family Resilience Questionnaire (Walsh, 2012) untuk mengukur resiliensi keluarga. Teknik analisis data yang digunakan adalah uji regresi. Temuan penelitian ini menunjukkan koherensi diri berkontribusi secara signifikan dan positif terhadap resiliensi keluarga dengan orang tua tunggal, dengan kontribusi sebesar 58,2\%. Temuan ini mengindikasikan pendekatan berbasis penguatan personal maupun keluarga dapat dipertimbangkan dalam memberdayakan keluarga dengan orang tua tunggal.
\end{abstract}

Kata kunci: resiliensi keluarga; koherensi diri; orang tua tunggal

\section{THE ROLE OF SENSE OF COHERENCE TOWARD FAMILY RESILIENCE OF SINGLE PARENTS}

\begin{abstract}
Family of single parents are prone to experience stress in life. To adapt optimally, it is important to ensure they are resilient, by knowing factor that contribute to family resilience. The aim of this study is to examine whether sense of coherence affect family resilience among family of single parents. With quantitative approach, this study involved 104 participants, selected by convenience sampling. We applied Sense of Coherence 13 (Antonovsky \& Sourani, 1988) to assess sense of coherence and Walsh Family Resilience Questionnaire (Walsh, 2012) to assess family resilience. The regression analysis revealed sense of coherence has significant positively contribution to family resilience among participants. The contribution of family sense of coherence to family resilience was $58,2 \%$. This result implied personal strength-based and family strength-based approached should be considered to empower family of single parents.
\end{abstract}

Keywords: family resilience; sense of coherence; single parents 


\section{PENDAHULUAN}

Fenomena ibu yang menjadi orang tua tunggal umum terjadi di Indonesia. Menurut Data Sosial Ekonomi Nasional, yang dilansir oleh Biro Pusat Data Statistik tahun 2011 (dalam Sirait \& Minauli, 2015), 3.644.160 ibu menjadi orang tua tunggal. Dari jumlah tersebut, sebanyak 781.520 ibu menjadi orang tua tunggal karena perceraian dengan suaminya, sementara sebanyak 2.882.640 ibu menjadi orang tua tunggal karena suaminya lebih dulu meninggal dunia. Fenomena orang tua tunggal telah dipaparkan dalam penelitian ilmiah, di antaranya penelitian yang dilakukan oleh Sirait dan Minauli (2015). Melalui pendekatan kualitatif, Sirait dan Minauli (2015) meneliti hardiness dua ibu yang menjadi orang tua tunggal karena kematian pasangan dan perceraian. Kemudian, peneliti pernah mewawancarai N, seorang ibu tunggal yang mengasuh enam anaknya di Jakarta. $\mathrm{N}$ menyatakan bahwa tantangan yang dihadapi oleh dirinya dan keluarga adalah terkait beban ekonomi, pola komunikasi, dan tidak adanya tempat untuk berbagi cerita (Wawancara Personal, 28 Juli, 2019).

Orang tua tunggal merupakan orang tua yang memelihara dan membesarkan anak-anak tanpa kehadiran atau dukungan pasangan (Duval \& Miller dalam Suprihatin, 2018). Meskipun sama-sama berstatus sebagai orang tua tunggal, ayah dan ibu memiliki kekhasannya masing-masing. Sebagai orang tua tunggal, ibu bukan hanya menjadi pencari nafkah untuk keluarganya, namun juga pengasuh dan pembimbing anak-anak (Layliyah, 2013). Sementara itu, sebagai orang tua tunggal, pada umumnya ayah cenderung berperan sebagai pencari nafkah dan mendapat bantuan dari keluarga besar dalam mengasuh anak-anak. Sebagai contoh, dalam penelitian yang dilakukan Astuti (2017), diketahui bahwa sebagai orang tua tunggal, ayah mendapatkan bantuan pengasuhan dari orang-orang terdekat atau keluarga besarnya. Selain itu, pada kasus orang tua tunggal karena perceraian, pada umumnya anak diasuh oleh ibu. Hal ini karena di berbagai budaya tugas pengasuhan lekat dengan ibu (Parmanti \& Purnamasari, 2015). Dengan demikian, dibandingkan ayah, ibu memiliki tanggung jawab ganda sebagai orang tua tunggal, yakni sebagai pengasuh sekaligus pencari nafkah, yang berpotensi sangat memengaruhi dinamika psikologisnya. Oleh karena itu, penelitian ini lebih fokus mengkaji ibu sebagai orang tua tunggal. Dengan demikian, istilah orang tua tunggal yang digunakan dalam penelitian ini, merujuk pada ibu tunggal.

Tantangan yang sama-sama dihadapi oleh ibu sebagai orang tua tunggal, baik yang disebabkan oleh perceraian maupun meninggal dunia, di antaranya adalah beban ekonomi (Nurfitri \& Waringah, 2018), konflik pekerjaan-keluarga (Faradina \& Fajrianthi, 2012), trauma (Sirait \& Minauli, 2015), perasaan sedih mendalam dan menutup diri (Nurfitri \& Waringah, 2018), stigma sosial (Sirait \& Minauli, 2015), dukungan sosial yang rendah (Sirait \& Minauli, 2015), kekhawatiran tentang tumbuh-kembang anak (Nurfitri \& Waringah, 2018), peran ganda (Nurfitri \& Waringah, 2018), stressful life event, dan sulit berkeluh kesah kepada orang-orang terdekat (Wawancara Personal, 28 Juli 2019). Tantangan lainnya adalah penyesuaian yang harus dilakukan karena sebelumnya, saat mengalami masalah berat, ia menghadapinya bersama suami, sementara sekarang tidak lagi (Layliyah, 2013). Berbagai situasi khas dan tantangan yang dihadapi ibu sebagai orang tua tunggal tidak hanya dihadapi oleh individu itu sendiri, namun juga dihadapi oleh keluarganya. Literatur sebelumnya mengungkapkan bahwa keluarga dengan orang tua tunggal melaporkan pola komunikasi yang kurang baik, dan konflik yang lebih banyak (Smetana, Yau, Restrepo, \& Braeges, 1991). Anggota dalam keluarga orang tua tunggal rentan terhadap berbagai risiko sosial dan fungsi psikologis yang buruk (Taylor \& Conger, 2014). Hasil penelitian kualitatif yang dilakukan oleh Wahyuni, Soemanto dan Haryono (2015) menunjukkan bahwa terdapat kenakalan sosiologis (perilaku menyimpang karena adanya dorongan untuk melanggar) yang dilakukan oleh anak-anak dari keluarga orang tua tunggal yaitu membohongi orang tua, membolos sekolah, dan sebagainya. Dengan demikian, perlu diupayakan strategi untuk membantu keluarga orang tua tunggal melewati tantangan yang ada. Mempertimbangkan bahwa orang tua tunggal dengan suami meninggal dunia atau bercerai sama-sama mengalami tekanan yang serupa, dalam penelitian ini, peneliti berfokus pada kedua tipe orang tua tunggal tersebut.

Meskipun terdapat tantangan yang dihadapi keluarga dengan ibu tunggal, namun ada keluargakeluarga yang berhasil melewati tantangan tersebut. Sebagai contoh, dalam penelitian Nurfitri dan Waringah (2018), terdapat sejumlah ibu tunggal yang mampu melakukan coping yang adaptif terhadap tantangan-tantangan yang dihadapinya. Keluarga yang dapat menghadapi tantangan tersebut memiliki kemampuan adaptasi terhadap tekanan yang ada, dapat memulihkan diri, dan bahkan bertumbuh secara positif melampaui kondisi sebelum tekanan terjadi. Kemampuan yang demikian dinamakan resiliensi keluarga. Dengan menjadi resilien, maka keluarga dapat mempertahankan keseimbangannya sebagai 
keluarga ketika dihadapi oleh masalah, menganggap bahwa masalah yang terjadi dapat diselesaikan bersama dan ada jalan keluarnya, mampu bertahan hidup dan mengubah keadaan menjadi lebih baik, serta mampu menjalankan fungsi sebagai anggota keluarga dengan baik (Hawley \& DeHaan, 1996). Oleh karena itu, perlu dilakukan penelitian untuk mengidentifikasi faktor yang dapat berperan bagi terbentuknya keluarga yang resilien pada keluarga dengan orang tua tunggal.

Resiliensi keluarga merupakan kemampuan atau kekuatan untuk kembali ke posisi semula setelah dihadapkan dengan situasi krisis dan mampu untuk mengatasi kesulitan, bertahan dari situasi stres dan bangkit dari situasi tersebut (Valentine \& Feinauer, 1993). Ahli lain mendefinisikan resiliensi keluarga sebagai karakteristik, dimensi, dan sifat dalam keluarga yang membantu keluarga dapat bertahan dari situasi yang krisis dan mampu beradaptasi pada perubahan yang terjadi (Gottlieb, 1998). Resiliensi keluarga terdiri dari tiga dimensi, yakni sistem keyakinan, pola organisasi, dan pola komunikasi (Walsh, 2006). Sistem keyakinan mencakup bagaimana sebuah keluarga memaknai krisis dan kesulitan yang mereka alami dengan mengaitkannya pada dukungan sosial, nilai-nilai budaya dan spiritual, kepercayaan generasi sebelumnya, dan harapan serta keinginan di masa yang akan datang (Walsh, 2006). Pola organisasi keluarga merupakan kemampuan keluarga dalam menggerakkan dan mengatur sumber daya setiap anggota keluarganya, menahan dari tekanan yang dialami, serta mengatur kembali keberfungsian keluarga agar sesuai dengan kondisi yang dapat berubah akibat suatu masalah (Walsh, 2006). Pola komunikasi merupakan kemampuan keluarga dalam mengomunikasikan setiap permasalahan yang terjadi pada seluruh anggota keluarganya dan bagaimana keluarga tersebut membantu proses pemecahan masalah tersebut (Walsh, 2006).

Keluarga yang resilien dapat terbentuk karena peran anggota keluarga lainnya. Menurut teori sistem keluarga, terdapat dinamika yang saling memengaruhi antara anggota-anggota keluarga dengan keluarga secara keseluruhan. Apa yang terjadi pada seorang anggota keluarga akan memengaruhi seluruh keluarga, demikian pula apa yang terjadi pada suatu keluarga akan memengaruhi individu-individu yang menjadi anggota di dalamnya (Lestari, 2012). Mengacu pada hal ini, keluarga yang resilien dapat terbentuk dari kontribusi anggota keluarganya. Salah satu tokoh sentral dalam keluarga orang tua tunggal yang mungkin dapat memengaruhi dinamika anggota keluarga lainnya adalah ibu. Ibu sebagai salah satu anggota keluarga, merupakan sosok yang dianggap berpengaruh dan panutan bagi anggota keluarga lainnya (Hadi, 2015). Ibu merupakan pengasuh utama dan pendidikan yang mentransfer nilai dan keterampilan hidup pada anggota keluarga yang lain (Zahrok \& Suarmini, 2018). Ketika anggota-anggota keluarga mampu mengatasi situasi sulit secara adaptif, atau menjadi keluarga yang resilien, peneliti berpendapat bahwa ibu menjadi figur yang berperan penting dalam mengembangkan kualitas-kualitas anggota keluarga yang demikian.

Menurut hasil penelitian, beberapa orang tua tunggal menunjukkan memiliki kompetensi dalam menyelesaikan masalah yang mereka hadapi, yaitu dengan cara melakukan self-management, meningkatkan hubungan sosial, serta meningkatkan well-being diri mereka (Rasi dkk, 2013). Hasil penelitian di atas juga menunjukkan bahwa orang tua tunggal yang memiliki hubungan yang baik dalam keluarganya memiliki karakteristik seperti mampu memanfaatkan sumber daya yang ada serta memiliki pemikiran yang rasional dan kritikal ketika menghadapi masalah (Rasi dkk, 2013). Dengan adanya karakteristik dan kualitas yang demikian pada orang tua tunggal, maka hal tersebut akan membantu mengarahkan anggota keluarga untuk menghadapi tantangan atau situasi sulit dengan efektif (Rasi dkk, 2013). Menurut Antonovsky (1993) berbagai kualitas yang mungkin dimiliki orang tua tunggal yang disebutkan di atas merupakan ciri-ciri koherensi diri.

Menurut Antonovsky (1993), koherensi diri merupakan kemampuan individu untuk mempersepsi bahwa setiap kejadian dapat diprediksi dan diatasi dengan sumber daya yang ada dan bermakna, serta melihat bahwa setiap masalah merupakan sebuah tantangan yang dapat dihadapi. Terdapat tiga dimensi dalam koherensi diri, yakni comprehensibility, manageability, dan meaningfulness. Comprehensibility merupakan kecenderungan seseorang dalam meyakini bahwa segala sesuatu yang terjadi pada dirinya merupakan sesuatu yang terstruktur, dapat diprediksi dan dapat dijelaskan; manageability merupakan kecenderungan seseorang dalam meyakini bahwa ia memiliki orang lain yang dapat membantunya dalam menghadapi sebuah masalah atau kejadian dalam hidupnya; dan meaningfulness merupakan kecenderungan yang dimiliki seseorang untuk melihat kehidupan sebagai hal yang bermakna, serta memberikan dorongan motivasi untuk terlibat dalam konfrontasi dengan masalah (Antonovsky, 1993). 
Gottlieb (1998) menemukan bahwa koherensi diri yang tinggi pada orang tua tunggal dengan anak disabilitas membuat mereka merasa tidak tertekan, memiliki sedikit masalah kesehatan, dan lebih merasa bersyukur sebagai orang tua. Ibu yang memiliki koherensi diri yang tinggi cenderung fleksibel dan mampu menemukan sumber daya yang tepat untuk mengatasi situasi sulit (Antonovsky, dalam Pisula \& Kossakowska, 2010). Kemudian, secara kognitif maupun emosional, ia mampu mengidentifikasikan akar masalah dan bisa menyiapkan segala sesuatu untuk menghadapi tekanan (Pisula \& Kossakowska, 2010). Selain itu, ibu dengan koherensi diri yang tinggi cenderung dapat mengelola emosi dan mengendalikan perilaku (Pisula \& Kossakowska, 2010). Koherensi diri yang tinggi dapat mengurangi timbulnya dampak negatif yang dihasilkan oleh situasi yang menekan. Sebaliknya, individu dengan koherensi diri yang rendah cenderung melaporkan kondisi kesehatan mental yang tidak baik dan mengalami lebih banyak dampak negatif dari situasi menekan (Srensen dkk, 2011).

Individu yang memiliki koherensi diri dapat memaknai krisis dan tantangan sebagai sesuatu yang positif, memilih strategi coping yang tepat, memiliki keterampilan problem solving dan adaptasi yang baik (Antonovsky, 1993). Dengan kemampuan-kemampuan tersebut, ibu yang memiliki koherensi diri dapat mendorong atau menggerakkan anggota keluarga yang lain untuk mengelola tekanan yang dihadapi secara tepat. Sebagai contoh, melalui proses berkesinambungan, ibu dapat mentransmisikan atau mengajarkan anggota keluarganya berbagai nilai positif dan keterampilan menyelesaikan masalah (Zahrok \& Suarmini, 2018). Dengan demikian, melalui hal tersebut, keluarga sebagai sebuah unit dapat menjadi lebih resilien karena mereka memiliki kemampuan adaptasi yang lebih baik saat menghadapi masalah.

Individu yang memiliki koherensi diri mampu mengembangkan harapan (Davidson, Feldman \& Margalit, 2012). Menurut Snyder, Rand, dan Sigmon (2005), adanya harapan mengindikasikan individu memiliki kemampuan merumuskan strategi untuk mencapai tujuan yang diinginkan (waypower). Dengan demikian, ketika individu orang tua tunggal memiliki kualitas yang demikian, ia dapat mendorong dan mengarahkan anggota keluarga yang lain untuk bersama-sama merumuskan cara-cara yang bisa dilakukan dalam pemecahan masalah dan mencari strategi untuk mengelola sumber daya yang dapat digunakan untuk mengatasi masalah. Strategi pemecahan masalah dan pengelolaan sumber daya merupakan unsur-unsur dalam membentuk keluarga yang resilien (Walsh, 2006). Kemudian, Sharabi, Levi dan Margalit (2012) menemukan bahwa koherensi diri yang tinggi memiliki keterkaitan dengan kohesivitas keluarga yang tinggi. Keluarga yang kohesif memungkinkan anggota-anggotanya memiliki hubungan yang erat satu sama lain, yang dapat dimanfaatkan dalam bekerja sama menyelesaikan masalah. Dengan demikian, ketika orang tua tunggal memiliki koherensi diri yang tinggi, memungkinkan ia dalam membangun kohesivitas keluarga yang pada akhirnya menjadikan keluarga resilien.

Hasil penelitian menyebutkan bahwa individu yang memiliki koherensi diri yang tinggi cenderung mengalami berkurangnya risiko depresi, atau gangguan psikologis lainnya (Pisula \& Kossakowska, 2010). Dengan demikian, orang tua tunggal yang memiliki koherensi diri yang tinggi cenderung terhindar dari depresi atau gangguan psikologis yang disebabkan adanya tekanan sebagai orang tua tunggal. Hal ini dapat mengurangi timbulnya faktor risiko dalam suatu keluarga, yang pada akhirnya dapat menjadikan keluarga resilien. Patterson (2002) menyebutkan, resiliensi keluarga merupakan hasil interaksi faktor risiko dengan faktor protektif. Makin kecil faktor risiko yang dimiliki keluarga, maka potensi keluarga untuk menjadi resilien lebih besar. Selain itu, hasil penelitian juga menyebutkan bahwa individu dengan koherensi diri tinggi memiliki kesehatan mental yang lebih baik (Behnke dkk., 2019). Kondisi mental yang sehat pada anggota keluarga dapat menjadi faktor protektif yang dapat meningkatkan resiliensi keluarga. Berdasarkan pemaparan sebelumnya, dapat disimpulkan bahwa individu dengan koherensi diri yang tinggi memiliki kualitas-kualitas yang dapat membantu keluarganya menjadi resilien. Dengan demikian, peneliti menduga koherensi diri pada ibu sebagai orang tua tunggal dapat berkontribusi terhadap resiliensi keluarga. Dugaan ini akan dibuktikan melalui penelitian yang bertujuan untuk mengetahui apakah terdapat peran koherensi diri terhadap resiliensi keluarga pada keluarga orang tua tunggal. Penelitian tentang orang tua tunggal di Indonesia telah dilakukan oleh Hasanah (2016), Wahyuni (2010), Faradina dan Fajrianthi (2012), Pratama (2014), serta Syahmala dan Asriwandari (2015). Penelitian tersebut meneliti sejumlah variabel, yakni psychological wellbeing, hardiness, konflik pekerjaan, manajemen konflik, dan resiliensi pada ibu yang menjadi orang tua tunggal. Berbagai penelitian tersebut pada umumnya hanya meneliti keterkaitan antar atribut personal pada orang tua tunggal dan belum meneliti sejauh mana atribut personal orang tua tunggal dapat memengaruhi dinamika keluarga secara keseluruhan. Penelitian ini mencoba untuk melihat apakah koherensi diri yang dimiliki orang tua tunggal dapat membantu keluarganya menjadi resilien. Dengan 
mempertimbangkan berbagai penjelasan yang telah dikemukakan pada paragraf sebelumnya, maka peneliti ingin mengkaji lebih lanjut mengenai peran koherensi diri terhadap resiliensi keluarga (berdasarkan perspektif satu anggota keluarga/uniperspektif).

\section{METODE}

Penelitian ini menggunakan pendekatan kuantitatif dengan desain non-eksperimen dan tipe asosiatif. Partisipan penelitian ini adalah 104 orang ibu yang merupakan orang tua tunggal karena perceraian maupun pasangan meninggal dunia. Peneliti memilih sampel partisipan dengan teknik nonprobability sampling, yakni convenience sampling, dimana partisipan dipilih berdasarkan ketersediaan dan kesediaan untuk terlibat dalam penelitian (Gravetter \& Forzano, 2016). Mayoritas partisipan berada dalam tahap perkembangan dewasa awal, yakni usia 20-40 tahun (57.8\%), berpendidikan tinggi (Diploma, Sarjana, dan Pascasarjana) (52\%), dengan penyebab menjadi orang tua tunggal adalah suami meninggal dunia $(63.4 \%)$.

Variabel kriteria dalam penelitian ini adalah resiliensi keluarga, sementara variabel prediktornya yaitu koherensi diri. Dalam penelitian ini, resiliensi keluarga didefinisikan sebagai kemampuan keluarga untuk beradaptasi, pulih, dan bangkit dari kesulitan yang dihadapi (Walsh, 2006). Instrumen yang digunakan untuk mengukur persepsi partisipan mengenai resiliensi keluarganya adalah Walsh Family Resilience Questionnaire atau WFRQ (Walsh, 2012) yang telah diterjemahkan ke dalam Bahasa Indonesia oleh Wandasari (2012) dan telah diadaptasi dalam penelitian Maulidia dkk. (2018). WFRQ terdiri dari 32 butir pernyataan lapor diri dengan rentang pilihan jawaban empat pada skala likert. Makin tinggi skor total yang diperoleh, maka menunjukkan bahwa makin tinggi resiliensi keluarga yang dipersepsikan partisipan. WFRQ terdiri dari tiga dimensi, yakni sistem keyakinan, pola organisasi, dan proses komunikasi. Contoh item dimensi sistem keyakinan adalah "Perasaan tertekan saat mengalami kesulitan, kami pandang sebagai hal yang wajar dan dapat dipahami"; contoh item dimensi pola organisasi adalah "Ketika terjadi kesulitan ada orang tua/wali yang memelihara, memberi arahan, bimbingan, dan perlindungan"; dan contoh item pola komunikasi adalah "Di dalam keluarga, kami dapat menyatakan pendapat dan jujur satu sama lain". Dalam penelitian ini, koefisien reliabilitas Cronbach's Alpha yang dihasilkan oleh WFRQ adalah .951 dengan corrected item total correlation berkisar antara .332-.768.

Koherensi diri dalam penelitian ini didefinisikan sebagai orientasi individu kepada hal yang positif dan keyakinan bahwa setiap kejadian di dunia ini dapat diamati, bermakna dan dapat diatasi dengan sumber daya yang ada (Antonovsky, 1993). Koherensi diri diukur melalui instrumen Sense of Coherence Scale 13 (SOC-13) dari Antonovsky (1993) yang dalam penelitian ini telah diterjemahkan, dinilai oleh ahli (expert judgement), serta dilakukan uji keterbacaan dan uji coba terpakai pada populasi yang sesuai. SOC-13 berupa skala lapor diri yang berisi 13 butir dengan rentang pilihan jawaban sebanyak tujuh pada skala likert. Makin tinggi skor total yang diperoleh, maka menunjukkan bahwa makin tinggi koherensi diri yang dipersepsikan partisipan. SOC-13 terdiri dari tiga dimensi, yaitu comprehensibility, manageability, dan meaningfulness. Contoh item dimensi comprehensibility adalah, "Apakah Anda memiliki perasaan dan ide yang sangat campur-aduk?"; contoh item dimensi manageability adalah, "Apakah Anda pernah dikecewakan oleh orang-orang yang Anda percayai?"; dan contoh item dimensi meaningfulness adalah, "Apakah Anda merasa bahwa Anda tidak begitu peduli dengan apa yang terjadi di sekitar Anda?". Dalam penelitian ini, koefisien reliabilitas Cronbach's Alpha yang dihasilkan oleh SOC-13 adalah .678 dengan mayoritas item memiliki corrected item total correlation berkisar antara 0,229-0,449, kecuali dua item yang memiliki corrected item total correlation di bawah 0,2 yaitu item nomor 11 (.062) dan item nomor 13 (.151). Dengan mempertimbangkan bahwa reliabilitas alat ukur ini tergolong baik, maka peneliti tidak menggugurkan item tersebut. Peneliti melakukan uji asumsi klasik, yakni uji normalitas dengan menggunakan uji Kolmogorov-Smirnov dan uji linearitas sebelum melakukan uji hipotesis. Dalam uji hipotesis, data penelitian dianalisis dengan menggunakan uji regresi sederhana untuk menilai seberapa besar pengaruh variabel prediktor terhadap variabel kriteria. Selain itu, peneliti juga melakukan kategorisasi skor koherensi keluarga dan resiliensi keluarga berdasarkan rumus Azwar (2010). 


\section{HASIL DAN PEMBAHASAN}

Berdasarkan hasil analisis statistik, rata-rata skor koherensi diri sebesar $M=42(S D=10.88)$. Sementara itu, ditinjau dari kategorisasi skor, mayoritas partisipan (74.04\%) memiliki skor koherensi diri yang berada dalam kategori menengah. Hal ini mengindikasikan bahwa partisipan mempersepsikan dirinya cukup mampu berorientasi positif terhadap situasi sulit yang terjadi, dan cukup mampu memandang situasi tersebut sebagai hal yang bermakna serta dapat diatasi dengan sumber daya yang ada (Antonovsky, 1993). Sementara itu, berdasarkan hasil analisis statistik, rata-rata skor resiliensi keluarga sebesar $M=79.20(S D$ = 23.32). Sementara itu, ditinjau dari kategorisasi skor, mayoritas partisipan (59.62\%) memiliki skor resiliensi keluarga yang berada dalam kategori menengah. Hal ini mengindikasikan bahwa partisipan menilai keluarganya cukup mampu untuk beradaptasi, pulih, dan bangkit dari kesulitan yang dihadapi (Walsh, 2006).

Tabel 1. Kategorisasi Skor Koherensi Diri dan Resiliensi Keluarga

\begin{tabular}{ccccc}
\hline & Kategorisasi & Rentang Skor & Frekuensi & Persentase \\
\hline Skor & Rendah & $13-31$ & 16 & 15.38 \\
Koherensi Diri & Sedang & $32-53$ & 77 & 74.04 \\
& Tinggi & $54-91$ & 11 & 10.58 \\
& Rendah & $13-31$ & 16 & 15.38 \\
Skor Resiliensi & Sedang & $32-53$ & 77 & 74.04 \\
Keluarga & Tinggi & $54-91$ & 11 & 10.58 \\
\hline
\end{tabular}

\section{Uji Asumsi Statistik}

Uji asumsi statistik, yakni uji normalitas dan uji linearitas, dilakukan sebelum melaksanakan uji hipotesis. Hasil uji normalitas unstandardized residual antara total skor koherensi diri dengan total skor resiliensi keluarga menunjukkan bahwa data berdistribusi normal karena nilai signifikansi yang diperoleh adalah $.092(p>.05)$.

Uji linearitas dilakukan sebagai syarat uji regresi, yakni untuk mengetahui apakah garis regresi $\mathrm{X}$ dan $\mathrm{Y}$ membentuk garis linear atau tidak. Hasil uji linearitas antara total skor koherensi diri dengan total skor resiliensi keluarga menunjukkan bahwa data linear karena nilai signifikansi linearity adalah $.000(p<.05)$.

\section{Uji Hipotesis: Koherensi Diri sebagai Prediktor Resiliensi Keluarga pada Keluarga dengan Orang} Tua Tunggal

Peneliti menguji hipotesis dengan teknik analisis regresi sederhana. Hasil yang diperoleh menujukkan koherensi diri memiliki pengaruh positif yang signifikan terhadap resiliensi keluarga yang menjadi partisipan penelitian ini, dengan besar kontribusi 58.2\%. Data selengkapnya dapat dilihat pada Tabel 2 di bawah ini.

Tabel 2. Hasil Uji Regresi Sederhana: Pengaruh Koherensi Diri terhadap Resiliensi Keluarga pada Keluarga dengan Orang Tua Tunggal

\begin{tabular}{ccccc}
\hline Variabel & R-Square & $\boldsymbol{F}$ & Sig & Persamaan \\
\hline $\begin{array}{c}\text { Koherensi Diri dan Resiliensi } \\
\text { Keluarga }\end{array}$ & .582 & 141.786 & .000 & Y $=99.091+0.763$ \\
& & & &
\end{tabular}

Temuan penelitian menunjukkan terdapat koherensi diri ibu yang menjadi orang tua tunggal berperan signifikan terhadap resiliensi keluarga berperan yang signifikan dari koherensi diri terhadap resiliensi keluarga pada partisipan penelitian, dengan besaran kontribusi 58.2\% $(p=.000)$. Temuan ini 
mengindikasikan adanya kesesuaian dengan teori sistem keluarga, mengenai adanya hubungan yang saling memengaruhi antara individu sebagai anggota keluarga, dengan keluarga (Lestari, 2012). Temuan penelitian ini juga mengindikasikan ibu merupakan sosok penting yang membantu keluarga beradaptasi dan bangkit dari tekanan ketika ayah tidak lagi ada (karena meninggal atau bercerai). Dalam budaya Indonesia, sosok ibu dianggap sebagai sosok yang memiliki peranan yang penting dalam keluarga, khususnya dalam mentransmisikan nila-nilai, (keterampilan hidup), dan sebagai contoh atau model bagi anggota keluarga lainnya (Hadi, 2015). Dengan koherensi diri yang tinggi, ibu dapat memaknai krisis dan tantangan sebagai sesuatu yang positif, memilih strategi coping yang tepat, serta memiliki keterampilan problem solving dan adaptasi yang baik (Antonovsky, 1993). Dengan demikian, ibu yang memiliki koherensi diri dapat mendorong atau menggerakkan anggota keluarga yang lain untuk mengelola tekanan yang dihadapi secara tepat sehingga pada akhirnya keluarga menjadi resilien. Selain itu, koherensi diri yang tinggi memungkinkan individu untuk mengembangkan kemampuan berharap (Davidson, Feldman \& Margalit, 2012), yakni merumuskan strategi untuk mencapai tujuan yang diinginkan (waypower) (Snyder, Rand, \& Sigmon, 2005). Dengan demikian, ketika individu orang tua tunggal memiliki kualitas yang demikian, ia dapat mendorong dan mengarahkan anggota keluarga yang lain untuk bersama-sama merumuskan cara-cara yang bisa dilakukan dalam pemecahan masalah dan mencari strategi untuk mengelola sumber daya yang dapat digunakan untuk mengatasi masalah. Strategi pemecahan masalah dan pengelolaan sumber daya merupakan unsur-unsur dalam membentuk keluarga yang resilien (Walsh, 2006). Kemudian, koherensi diri yang dimiliki ibu merupakan faktor protektif bagi keluarga dengan orang tua tunggal yang melindungi mereka dari dampak negatif tekanan yang ditimbulkan, dan faktor protektif sendiri merupakan komponen untuk membentuk resiliensi keluarga (Walsh, 2012).

Temuan ini menyokong hasil penelitian sebelumnya yang menyebutkan adanya korelasi positif dan signifikan antara koherensi dengan resiliensi keluarga (Maulidia dkk, 2018; Uswatunnisa dkk, 2019). Penelitian yang dilakukan Maulidia dkk (2018) dan Uswatunnisa dkk (2019) meneliti tentang koherensi keluarga. Baik koherensi keluarga maupun koherensi diri berakar dari konsep atau teori yang sama, yakni salutogenesis yang dikemukakan Antonovsky \& Sourani (1988). Perbedaannya adalah pada penerapannya. Koherensi keluarga diterapkan pada keluarga, sementara koherensi diri pada individu.

Kontribusi koherensi diri terhadap resiliensi keluarga adalah sebesar 58.2\%. Temuan ini mengindikasikan bahwa terdapat $41,8 \%$ faktor lain selain koherensi diri yang berkontribusi pada resiliensi keluarga. Hasil-hasil penelitian terdahulu menunjukkan bahwa terdapat sejumlah faktor yang berkorelasi atau berkontribusi terhadap resiliensi keluarga, yakni dukungan sosial (Greeff \& van der Walt, 2010), harapan (Iriani \& Syafiq, 2017), koherensi keluarga (Maulidia dkk, 2018; Uswatunnisa dkk, 2019), strategi coping (Greeff \& van der Walt, 2010), dan komunikasi antaranggota keluarga (Pandanwati \& Suprapti, 2012).

\section{Uji Beda Skor Koherensi Diri dan Resiliensi Keluarga Ditinjau dari Variabel Demografi}

Hasil penelitian sebelumnya menemukan adanya perbedaan skor koherensi diri bila ditinjau dari tingkat pendidikan, penghasilan, dan usia (Eli dkk, 2016). Peneliti melakukan analisis uji beda skor koherensi diri ditinjau dari variabel-variabel tersebut dengan menggunakan one-way anova. Hasilnya menunjukkan bahwa tidak terdapat perbedaan skor koherensi keluarga apabila ditinjau dari segi usia $(F$ $=9.490, p=0.962)$, namun terdapat perbedaan yang signifikan bila ditinjau dari tingkat pendidikan $(F$ $=0.252, p=0.000)$, dan penghasilan $(F=2.736, p=0.001)$. Hasil selengkapnya dapat dilihat pada Tabel 3 berikut. 
Tabel 3. Hasil Uji Beda Skor Koherensi Diri Ditinjau dari Variabel Demografi

\begin{tabular}{llcc}
\hline Variabel & $\boldsymbol{F}$ & Mean & Sig. $(\boldsymbol{p})$ \\
\hline Usia & 9.490 & & .962 \\
Pendidikan & & & \\
$\quad \begin{array}{l}\text { Pendidikan Dasar } \\
\text { Pendidikan Menengah }\end{array}$ & .252 & 40.54 & \\
$\quad$ Pendidikan Tinggi & & 40.54 & .000 \\
& & & \\
Pendapatan & & 50.89 & \\
$<2.000 .000$ & 2.736 & 39.26 & .001 \\
$>2.000 .000$ & & 49.74 & \\
\hline
\end{tabular}

Hasil penelitian sebelumnya menemukan adanya perbedaan skor koherensi diri bila ditinjau dari tingkat pendidikan dan penghasilan (Greeff \& van der Walt, 2010; Benzies \& Mychasiuk, dalam Lennon \& Heaman, 2015). Peneliti melakukan analisis uji beda skor resiliensi keluarga ditinjau dari variabel-variabel tersebut dengan menggunakan one-way anova. Hasilnya menunjukkan bahwa terdapat perbedaan skor resiliensi keluarga yang signifikan bila ditinjau dari tingkat pendidikan $(F=$ $.569, p=.000)$ dan penghasilan $(F=.346, p=.001)$. Peneliti juga melakukan analisis uji beda skor resiliensi keluarga ditinjau dari penyebab menjadi keluarga dengan orang tua tunggal (suami meninggal atau bercerai). Hasilnya menunjukkan bahwa terdapat perbedaan skor resiliensi keluarga yang signifikan bila ditinjau dari variabel tersebut $(F=.303, p=.000)$. Hasil selengkapnya dapat dilihat pada Tabel 4 berikut:

Tabel 4. Hasil Uji Beda Skor Resiliensi Keluarga Ditinjau dari Variabel Demografi

\begin{tabular}{lccc}
\hline Variabel & $\boldsymbol{F}$ & Mean & Sig. $(\boldsymbol{p})$ \\
\hline Pendidikan & .569 & 68.92 & .000 \\
Pendidikan Dasar & & 68.92 & \\
Pendidikan Menengah & & 88.72 & \\
Pendidikan Tinggi & & & .000 \\
Pendapatan & .346 & 64.7 & \\
$<2.000 .000$ & & 87.51 & \\
$>2.000 .000$ & & & .000 \\
Penyebab menjadi & .303 & & \\
Orang Tua Tunggal & & 83.93 & \\
Bercerai & & 77.37 & \\
Meninggal dunia & & & \\
\hline
\end{tabular}

Uji statistik menunjukkan bahwa terdapat perbedaan yang signifikan pada skor koherensi diri maupun skor resiliensi keluarga bila ditinjau dari tingkat pendidikan dan penghasilan, yang mana hal ini mendukung penelitian sebelumnya (Eli dkk, 2016; Greeff \& van der Walt, 2010; Benzies \& Mychasiuk, dalam Lennon \& Heaman, 2015; Geyer, dalam Ängarne-Lindberg\& Wadsby, 2011), yang menunjukkan bahwa tingkat pendidikan dan penghasilan yang lebih tinggi memungkinkan diri lebih koheren dan keluarga lebih resilien. Ketika anggota keluarga, dalam hal ini ibu yang menjadi partisipan penelitian ini, memiliki tingkat pendidikan yang lebih tinggi, maka ia cenderung lebih memiliki pengetahuan dan keterampilan dalam mencari solusi, melakukan reframing terhadap tekanan secara lebih positif, serta mengupayakan sumber daya yang dibutuhkan dalam mengatasi tekanan. Berbagai hal tersebut membuat individu tidak hanya meningkatkan koherensi diri, namun juga membantu keluarga menjadi lebih resilien. Kemudian, dengan tingkat penghasilan yang lebih tinggi, memungkinkan keluarga mengakses sumber daya-sumber daya yang dibutuhkan yang memiliki nilai lebih, misalnya layanan kesehatan, layanan pendidikan, layanan pendampingan psikologi, dan sebagainya. 
Temuan penelitian ini juga menemukan bahwa keluarga dengan orang tua tunggal yang disebabkan oleh kematian suami memiliki skor resiliensi keluarga yang lebih rendah dibandingkan keluarga orang tua tunggal karena perceraian. Hal ini berbeda dengan penelitian sebelumnya yang menunjukkan keluarga orang tua tunggal karena perceraian maupun kematian suami sama-sama memiliki kompetensi dalam menyelesaikan masalah yang mereka hadapi, seperti mampu memanfaatkan sumber daya yang ada, memiliki pemikiran yang rasional dan kritikal ketika menghadapi masalah (Rasi dkk, 2013), yang merupakan karakteristik keluarga yang resilien.

Terdapat keterbatasan-keterbatasan dalam penelitian ini. Pertama, peneliti mengalami kendala dalam memperoleh partisipan penelitian. Jumlah partisipan penelitian ini hanya 104 orang sehingga hasil penelitian tidak dapat digeneralisasi. Selanjutnya, penelitian ini hanya menganalisis pengaruh koherensi diri terhadap resiliensi keluarga, dan tidak meneliti faktor-faktor yang memerantarai hubungan keduanya. Penelitian selanjutnya dapat meneliti faktor-faktor yang mungkin memediasi hubungan antara koherensi diri dengan resiliensi keluarga. Kemudian, sumbangan efektif yang dihasilkan koherensi diri terhadap resiliensi keluarga hanya sebesar $58.2 \%$, sementara sebesar $41.8 \%$ dipengaruhi oleh faktor lainnya yang tidak diteliti dalam penelitian ini. Penelitian selanjutnya dapat diarahkan untuk meneliti faktor-faktor yang belum teridentifikasikan tersebut.

\section{SIMPULAN}

Penelitian ini menghasilkan temuan yakni terdapat peran yang positif dan signifikan dari koherensi diri ibu sebagai orang tua tunggal terhadap resiliensi keluarga. Hal ini berarti ibu yang mampu memaknai tekanan sebagai hal yang positif, dapat dikendalikan, serta mampu mengupayakan dan mengelola sumber daya untuk mengatasi tekanan tersebut dapat membuat keluarganya menjadi mampu beradaptasi, memulihkan diri, dan bangkit dari situasi sulit. Hasil penelitian ini memperluas pemahaman bahwa pembentukan keluarga yang resilien dapat diinisiasi oleh satu anggota keluarga, dalam hal ini ibu, yang memiliki koherensi diri yang tinggi. Dengan demikian, program pemberdayaan keluarga dengan orang tunggal dapat dimulai dengan menguatkan ibu sebagai sosok sentral dalam keluarga. Selain ibu, anggota-anggota keluarga lainnya dapat juga dilibatkan dalam program intervensi yang dapat meningkatkan koherensi diri mereka.

\section{DAFTAR PUSTAKA}

Ängarne-Lindberg, T., \& Wadsby, M. (2011). Sense of coherence in young adults with and without experience of parental divorce in childhood. Journal of Divorce \& Remarriage, 52(5), 309321.

Antonovsky, A., \& Sourani, T. (1988). Family sense of coherence and family adaptation. Journal of Marriage and Family, 50(1), 79-92.

Antonovsky, A. (1993). The structure and properties of the sense of coherence scale. Social Science \& Medicine, 36(6), 725-733.

Astuti, D. (2017). Keterlibatan pengasuhan ayah sebagai orang tua tunggal dengan anak Perempuannya setelah terjadinya perceraian (Studi kasus komunikasi antarpribadi di desa Kwangsan, kecamatan Jumapolo). Komuniti, VIII(1), 19-34.

Azwar, S. (2010). Penyusunan skala psikologi. Yogyakarta: Pustaka Pelajar.

Behnke, A., Conrad, D., Kolassa, I. T., \& Rojas, R. (2019). Higher sense of coherence is associated with better mental and physical health in emergency medical services: results from investigations on the revised sense of coherence scale (SOC-R) in rescue workers. European Journal of Psychotraumatology, 10(1), 1-12)

Cohen, O. \& Dekel, R. (2000). Sense of coherence, ways of coping, and well being of married and divorced mothers. Contemporary Family Therapy, 22(4), 467-486.

Davidson, O.B., Feldman, D.B., \& Margalit, M. (2012). A focused intervention for $1^{\text {st }}$-year college students: promoting hope, sense of coherence and self-efficacy. The Journal of Psychology, 146(3), 333-352. 
Eli, K., Sorjonen, K., Mokoena, L., Pietrobelli, A., Flodmark, C.E., Faith, M.S., \& Nowicka, P. (2016). Associations between maternal sense of coherence \& controlling feeding practices: The importance of resilience and support in families of preschoolers. Appetite, 105, 134-143.

Faradina, A.F., \& Fajrianthi. (2012). Konflik pekerjaan-keluarga dan coping pada single mothers. Jurnal Psikologi Industri dan Organisasi, 1(2), 104-111.

Gottlieb, A. (1998). Single mothers of children with disabilities: The role of sense of coherence in managing multiple challenges. In H. I. McCubbin, E. A. Thompson, A. I.Thompson, \& J. E. Former.(Eds.), Sense of coherence and resiliency: Stress, coping and health (pp. 189-204).

California: Sage Publication, Inc.

Gravetter, F. J., \& Forzano, L. A. B. (2016). Research methods for the behavioral sciences. USA: Cengage Learning.

Greeff, A. P., \& van der Walt, K. J. (2010). Resilience in families with an autistic child. Education and Training in Autism and Developmental Disabilities, 45(3), 347-355.

Hadi, W. (2015). Peran ibu single parent dalam membentuk kepribadian anak: Kasus dan solusi. El Banat, 9(2), 301-320.

Hasanah, U. (2016). Psychological well-being pada single parent mother yang ditinggal suaminya meninggal dunia. Skripsi. Fakultas Psikologi Universitas Muhammadiyah Surakarta, Surakarta, Indonesia.

Hawley, D. R., \& DeHaan, L. (1996). Toward a definition of family resilience: Integrating life-Span and family perspectives. Family Process, 35(3), 283-298.

Iriani, L. P., \& Syafiq, M. (2017). Gambaranhope pada seorang penyandang tunarungu wicara yang berprestasi. Character: Jurnal Psikologi Pendidikan, 4(3), 1-6.

Layliyah, Z. (2013). Perjuangan hidup single parent. Jurnal Sosiologi Islam, 3(1), 88-102.

Lennon, S. L., \& Heaman, M. (2015). Factors associated with family resilience during pregnancy among inner-city women. Midwifery, 31(10), 957-964.

Lestari, S. (2012). Psikologi keluarga: Penanaman nilai dan penanganan konflik dalam keluarga. Jakarta: Kencana Prenada Media Group.

Maulidia, F. N., Kinanthi, M. R., Fitria, N., \& Permata, A. S. (2018). Peran koherensi terhadap kelentingan keluarga yang memiliki anak dengan spektrum autistik (ASA). Jurnal Ilmu Keluarga \& Konsumen, 11(1), 13-24.

Nurfitri, D., \& Waringah, S. (2018). Ketangguhan pribadi orang tua tunggal: Studi kasus pada perempuan pasca kematian suami . Gadjah Mada Journal of Psychology (GamaJoP), 4(1), 1124.

Pandanwati, I. S., \& Suprapti, V. (2012). Resiliensi keluarga pada pasangan dewasa madya yang tidak memiliki anak. Jurnal Psikologi Pendidikan dan Perkembangan, 1(3), 1-8.

Patterson, J. M. (2002). Integrating family resilience and family stress theory. Journal of Marriage and Family, 64(2), 349-360.

Parmanti, P., \& Purnamasari, S. E. (2015). Peran ayah dalam pengasuhan anak. InSight, 17(2), 81-90.

Pisula, E., \& Kossakowska, Z. (2010). Sense of coherence and coping with stress among mothers and fathers of children with autism. Journal of Autism and Developmental Disorders, 40, 14851494.

Pratama, B. E (2014). Resiliensi di Rumah Tangga pada Ibu sebagai Orang Tua Tunggal. Skripsi. Universitas Muhammadiyah Surakarta, Surakarta, Indonesia.

Rasi, H. A., Moula, A., Puddephatt, A. J., \& Timpka, T. (2013). Empowering single mothers in Iran: Applying a problem-solving model in learning groups to develop participants' capacity to improve their lives. British Journal of Social Work, 43(5), 833-852.

Sharabi, A., Levi, U., Margalit, M. (2012). Children's lonliness, sense of coherence, family climate, and hope: Developmental risk and protective factors. The Journal of Psychology, 146, 61-83.

Sirait, N. Y. D., \& Minauli, I (2015). Hardiness pada single mother. Jurnal Diversita, 1(2), 28-38.

Smetana, J. G., Yau, J., Restrepo, A., \& Braeges. J. L. (1991). Adolescent-parent conflict in married and divorced families. Developmental Psychology, 27(6), 1000-1010.

Snyder, C. R., Rand, K. L., \& Sigmon, D. R. (2005). Hope theory: A member of the positive psychology 
family. In C. R. Snyder \& S.J. Lopez. (Eds) Handbook of positive psychology (pp. 257-276). New York: Oxford University Press.

Srensen, T., Klungsyr, O., Kleiner, R., \& Klepp, O. M. (2011). Social support and sense of coherence: Independent, shared and interaction relationships with life stress and mental health. International Journal of Mental Health Promotion, 13(1), 27-44.

Suprihatin, T. (2018). Dampak pola asuh orang tua tunggal (single parent parenting) terhadap perkembangan remaja. Prosiding Seminar Psikologi Unissula, 145-160. Fakultas Psikologi Universitas Islam Sultan Agung.

Syahmala, N., \& Asriwandari, H. (2015). Perempuan orang tua tunggal dalam pelaksanaan fungsi keluarga di kecamatan Dumai Selatan kota Dumai. Jom FISIP, 2(2), 1-16.

Taylor, Z. E., \& Conger, R. D. (2014). Risk and resilience processes in single-mother families: An interactionist perspective. In: Sloboda Z., \& Petras H. (eds) Defining prevention science. Advances in prevention science (pp. 195-217). New York: Springer Science.

Uswatunnisa, A., Brebahama, A., \& Kinanthi, M.R. (2019). Peran family sense of coherence terhadap resiliensi keluarga yang memiliki anak tunanetra ditinjau dari perspektif ibu. Jurnal Psikogenesis, 7(2), 201-214.

Valentine, L., \& Feinauer, L. L. (1993) Resilience factors associated with female survivors of childhood sexual abuse. American Journal of Family Therapy. 21(3), 216-224.

Wahyuni, S. D. (2010). Konflik dalam keluarga single parent: studi deskriptif kualitatif tentang konflik dalam keluarga single parent di desa Pabelan kecamatan Kartasura Sukoharjo. Skripsi. Universitas Sebelas Maret, Surakarta, Indonesia.

Wahyuni, S., Soemanto, RB., \& Haryono, B. (2015). Kenakalan pelajar dalam keluarga single parent: studi kasus pada pelajar dalam keluarga single parent di Sekolah Menengah Atas Negeri 1 Girimarto Wonogiri tahun 2012/2013. Jurnal Analisa Sosiologi, 4(2), 1-9.

Walsh, F. (2006). Strengthening family resilience (2nd Ed.). New York: The Guilford Press.

Walsh, F. (2012). Facilitating family resilience: Relational resources for positive youth development in conditions of adversity. Dalam Ungar M. (Eds) The Social Ecology of Resilience: A handbook of theory and practice (pp. 173-185). New York, USA: Springer.

Wandasari, W. (2012). Hubungan antara resiliensi keluarga dan koherensi keluarga pada mahasiswa yang berasal dari keluarga miskin. Skripsi. Universitas Indonesia, Depok, Indonesia.

Zahrok, S., \& Suarmini, N. W. (2018). Peran perempuan dalam keluarga. Prosiding SEMATEKSOS 3 "Strategi Pembangunan Nasional Menghadapi Revolusi Industri 4.0", 61-65. 